\title{
Kajian Awal Pemanfaatan Rumput Teki (Fimbristylis sp), Linggi (Penicum sp) dan Sianik (Carex sp) sebagai Serat Alami untuk Bahan Alat Penangkapan Ikan
}

\author{
Nofrizal $^{1 *)}$, Muchtar Ahmad $^{2)}$, Irwandy Syofyan ${ }^{1)}$ dan Ied Habibie ${ }^{2)}$ \\ ${ }^{1}$ Laboratorium Bahan dan Rancangan Alat Penangkapan Ikan, Fakultas Perikanan Ilmu Kelautan Universitas Riau, Pekanbaru \\ ${ }^{2)}$ Laboratorium Ekoteknologi, Fakultas Perikanan Ilmu Kelautan Universitas Riau, Pekanbaru 28293
}

Diterima 03-02-2010 Disetujui 14-05-2011

\begin{abstract}
This research was aimed to study about the potential of fiber structure teki grass (Fimbristylis sp), linggi grass (Penicum sp) and sianik grass (Carex sp) as natural fibre for fishing gear materials. The parameter of this research are; water content, elongation, breaking strength and histology of the fiber. This research used the observation and experimental method. The observation method is used to know the fiber structure and water content of teki grass, linggi grass and sianik grass. The experimental method was used to test the breaking strength and elongation of the objects in wet and dry condition. Based on the histology observation, teki grass has an epidermis layers as fiber structure. It consists of parenchyma tissue and collenchymas tissue.Fiber structure of linggi grass and sianik grass are similar with teki grass. Sianik grass has the most excessive epidermis layer than others i.e. 5.57 gram. The average water content of teki grass is 1.03 gram, and linggi grass is 0.17 gram. Based on the breaking strength test, sianik grass is stronger than others with average strength $9.05 \mathrm{kgf}$ in wet condition and $9.75 \mathrm{kgf}$ in dry condition. Meanwhile, breaking strength of the teki grass and linggi grass is $3.20 \mathrm{kgf}$ and $4.16 \mathrm{kgf}$ in wet condition and 4.30 $\mathrm{kgf}$ and $5.25 \mathrm{kgf}$ in dry condition. The average of the elongation of sianik grass is longer than others i.e. $24.50 \mathrm{~mm}$ in wet condition and $18.75 \mathrm{~mm}$ in dry condition. The elongation of teki grass is $9.05 \mathrm{~mm}$ in wet condition and 11.10 in dry condition. The average of linggi grass elongation is $12.20 \mathrm{~mm}$ in wet condition and $12.90 \mathrm{~mm}$ in dry condition. Based on the breaking strength and the elongation test, the result showed that sianik grass is the most potential natural fiber as fishing gear material.
\end{abstract}

Keywords: breaking strength, elongation, fiber structure, fishing gear, natural fiber, water content

\section{PENDAHULUAN}

Semakin mahalnya harga serat sintetis yang terbuat dari bahan kimiawi untuk bahan baku alat penangkapan ikan seperti polyamide, polyethylene, fibreglass, monofilamen yang umumnya berasal dari sumber bahan yang tidak dapat diperbaharuhi mendorong ditemukan serat alami sebagai bahan alternatif yang berasal dari sumber yang dapat diperbaharui melalui usaha budidaya. Penggunaan serat alami pada beberapa bagian alat penangkapan ikan memiliki beberapa sifat yang menguntungkan. Disamping harganya relatif lebih murah dari serat sintetis, beberapa serat alami juga memiliki kecepatan tenggelam (sinking speed) yang baik karena serat ini menyerap air. Juga sebagian besar serat alami ini lebih mudah terurai apa bila bagian bahan ini terbuang sebagai sampah ke laut sehingga memperkecil terjadinya "ghost fishing" di perairan umum.

Selain memilih bahan baku yang dapat dipintal menjadi tali atau benang bahan alat penangkapan ikan, maka idealnya ada beberapa kriteria yang harus dimiliki, yaitu mudah didapat di daerah setempat, teknologi pengolahanya tidak terlalu sulit sehingga biaya relatif murah dan bahan baku tersebut tidak berasal dari jenis tumbuh-tumbuhan yang langka atau dilindungi, tapi mudah dibudidayakan (renewable resources). Banyak tumbuhan di alam yang belum dimanfaatkan karena belum dikaji sifat dan kesesuaiannya sebagai bahan baku alat tangkap. Oleh karena itu, peneliti tertarik untuk melakukan penelitian dasar mengenai serat alami yang berasal dari rumput teki (Fimbristylis sp), rumput linggi (Penicum sp), dan rumput sianik (Carex sp) untuk dijadikan bahan baku tali yang digunakan pada alat penangkapan ikan. Karena di samping ketiga jenis tumbuhan ini banyak dan mudah ditemukan di sekitar lingkungan rawa-rawa dan sejauh ini tumbuhtumbuhan tersebut juga belum dimanfaatkan. Sehingga, hypothesis yang diajukan dalam penelitian ini ialah ketiga jenis rumput yang menjadi objek penelitian memiliki potensi untuk dijadikan bahan baku tali dari serat alami pada alat penangkapan ikan jika ditinjau dari aspek fisika.

\section{BAHANDANMETODE}

Peralatan dan bahan penelitian. Penelitian ini dilakukan di Laboratorium Alat Penangkapan Ikan Jurusan Pemanfaatan Sumberdaya Perairan Fakultas Perikanan dan Ilmu Kelautan Universitas Riau. Peralatan yang digunakan 
untuk pelaksanaan penelitian ini adalah strength tester, jangka sorong, mikroskop, pisau silet, timbangan digital, dan kamera digital. Sedangkan bahan yang digunakan antara lain rumput teki (Fimbristylis sp), linggi (Penicum $\mathrm{sp)}$ dan sianik (Carex sp), akuades, dan tisu gulung.

Metode. Metode yang akan digunakan dalam penelitian ini adalah metode observasi dan metode eksperimental. Metode observasi digunakan untuk melakukan pengamatan terhadap morphologi struktur serat dan kadar air rumput sianik, linggi dan teki. Sedangkan metode eksperimental digunakan untuk menguji kekuatan putus dan kemuluran sampel dari ketiga tumbuhan yang menjadi objek penelitian.

Analisis data. Pengujian kekuatan putus dan kemuluran bahan uji dilakukan pada kondisi basah dan kering. Selanjutnya data yang diperoleh dari hasil pengamatan dan uji coba bahan ditabulasikan ke dalam tabel, lalu dianalisis secara deskriptif. Sedangkan analisis data yang digunakan dalam penelitian ini adalah menggunakan uji t dan statistik deskriptif.

\section{HASIL DAN PEMBAHASAN}

Teknologi perikanan terutama yang menyangkut bahan, bentuk, fungsi alat penangkapan yang dipakai telah mengalami perkembangan yang menjadi penting artinya dalam industri perikanan. Ini merupakan perangsang yang kuat bagi lembaga-lembaga ilmiah maupun industri dan usahawan, yang tujuannya secara langsung ataupun tidak langsung di bidang perikanan untuk mempelajari dan meneliti permasalahan penangkapan yang menyangkut efisien dan efektifitas dengan segala aspek (Asrianto 1978).

Menurut Hamidy et al. (1982), tali yang digunakan pada pembuatan atau perangkaian alat tangkap ditinjau dari bahan dasarnya termasuk pada bagian bahan tekstil. Bahan tekstil dapat dibagi dua yaitu: dari serat alam dan serat buatan. Menurut Dinas Perikanan Tingkat I Riau (1996), perkembangan sarana dan alat penangkapan ikan juga terjadi pada bahan yang digunakan oleh alat penangkapan ikan itu sendiri, seperti pengolahan serat alami menjadi bahanbahan sintetis untuk membuat jaring. Ditambahkan oleh Xiao et al. (2000), karateristik komposite beberapa serat alami seperti rami, sisal, yute, hemp, flax dan serat bambu dapat digunakan untuk bahan serat komposit untuk Fiber glass (FRP) dan plastik.

Menurut Sandoz (1952), serat alami yang biasa digunakan biasanya berasal dari katun, jute, linen, sisal, manila, hennep, rosella dan lain-lain. Sedangkan Cole dan Roger (1985), berpendapat bahwa benang katun adalah benang yang terpopuler dipergunakan untuk bahan jaring gillnet, purse seine, trap net dan sebagainya. Oleh karena itu timbullah gagasan untuk menjadikan rumput teki, sianik dan linggi sebagai objek kajian bahan baku tali sebagai bahan alat penangkapan ikan. Selain itu rumput ini banyak terdapat di sekitar lingkungan kita dan belum pernah dimanfaatkan, apalagi sebagai bahan baku tali ataupun benang.

Histologi Teki (Fimbristylis sp), Sianik (Carex sp) dan Linggi (Penicum sp). Pengamatan histologi serat penting diketahui untuk dapat digunakan sebagai bahan baku tali ataupun benang untuk alat penangkapan ikan. Kekuatan tali atau benang sangat ditentukan oleh bentuk dan kekuatan serat yang digunakan. Berdasarkan pengamatan histologi di laboratorium diperoleh enam bentuk preparat yang terdiri dari jaringan serat rumput teki (Fimbristylis sp), linggi (Penicum sp) dan sianik (Carex $\mathrm{sp})$. Dari ketiga jenis tumbuhan ini diperoleh masing-masing dua posisi preparat yang berbeda, yaitu secara melintang dan membujur. Adapun untuk jelasnya bentuk jaringan serat yang diamati di bawah miskroskop dapat dilihat pada Gambar 1 A dan B.

Berdasarkan hasil pengamatan dapat diketahui bahwa rumput teki memiliki struktur serat jaringan kolenkim yang berbentuk bulat yang menyebar berkelompok namun tidak merata. Jaringan ini memiliki peran dalam pembentukan serat pada rumput ini. Jaringan rumput teki memiliki lapisan epidermis dan lapisan dermis. Lapisan epidermis pada tumbuhan ini terdiri dari jaringan parenkim, jaringan kolenkim dan jaringan sklerenkim. Sedangkan lapisan dermis pada jaringan tumbuhan ini terdiri dari lapisan urat serat tumbuhan, lapisan jaringan penghubung dan lapisan perasa.

Jaringan kolenkim berfungsi sebagai serat pada tumbuhan. Jaringan yang berbentuk bulat yang menyebar pada lapisan epidermis. Jaringan ini merupakan jaringan penunjang yang masih muda, yang merupakan sel hidup pada dinding sel yang mengalami penebalan selulosa. Berdasarkan pengamatan dari Gambar 1 A ternyata jaringan kolenkim yang dimiliki oleh serat teki ini tidak terlalu banyak dan letaknya tersebar.

Semakin banyak jaringan kolenkim maka akan semakin banyak serat yang dihasilkan. Demikian juga dengan letaknya, semakin rapat dan merata letaknya, maka semakin baik pula kekuatan serat tumbuhan tersebut. Pada penampang melintang juga dapat dilihat jaringan dermis berbentuk hitam kehijau-hijauan. Jaringan dermis merupakan jaringan urat daging. Sedangkan pada penampang 
membujur serat teki dapat dilihat jaringan epidermis (bagian yang memanjang seperti balok) dan parenkim (bagian yang agak bulat). Kedua jaringan ini memiliki fungsi untuk melindungi jaringan lainnya serta membantu juga dalam pembentukan serat. Selain itu, serat rumput teki disusun pula oleh jaringan epidermis, yaitu bagian yang menyerupai bentuk balok. Sedangkan bagian yang agak bulat pada gambar tersebut adalah jaringan parenkim. Kedua jaringan inilah yang memiliki peran dalam pembentukan serat tumbuhan dan untuk melindungi jaringan yang lainnya.

Jaringan kolenkim rumput sianik terlihat lebih jelas, dimana pada rumput sianik ini hampir seluruh permukaannya didapati jaringan kolenkim. Selain itu letak dan jumlahnya merata serta ukurannya jauh lebih besar dibandingkan dengan jaringan kolenkim yang terdapat pada serat rumput teki maupun linggi. Pada penampang serat rumput sianik, jaringan epidermis dan parenkimnya juga memiliki jumlah yang lebih banyak dan letaknyapun lebih merata di permukaan serat. Hal ini memungkinkan rumput sianik memiliki struktur serat yang relatif akan lebih kuat jika dibandingkan dengan rumput teki dan linggi (Gambar $2 \mathrm{~A}$ dan B).

Berdasarkan hasil pengamatan histologi rumput linggi ternyata jaringan epidermis dan jaringan parenkimnya kurang jelas terlihat. Jaringan epidermis merupakan jaringan yang berfungsi menutupi permukaan tumbuhan. Sedangkan jaringan parenkim adalah jaringan dasar yang terdapat hampir pada semua bagian jaringan tumbuhan dan juga mengisi jaringan tumbuhan baik pada akar, batang, daun, biji dan buah.

Rumput linggi ini juga memiliki struktur serat yang sama dengan rumput sianik. Perbedaannya hanya terletak pada jumlah jaringan dan susunannya. Pada penampang melintang rumput linggi terlihat jumlah jaringan kolenkim lebih banyak dan letaknya hampir merata, sehingga serat lebih kuat jika dibandingkan dengan serat rumput teki (Gambar 3 A). Terlihat jumlah rongga besar pada bagian melintang rumput linggi ini yang merupakan lubang pada bagian dalam rumput ini. Pada penampang membujur serat linggi, jaringan epidermis dan parenkimnya pun lebih merata dan jumlahnya lebih banyak. Sebagai contoh struktur parenkim dan epidermis rumput linggi dapat dilihat pada Gambar 4 A dan B.

Menurut Ataladjar (1991), mengatakan serat alam yang didapat dari tumbuhan, hewan dan mineral digunakan oleh manusia sejak ribuan tahun yang lalu. Serat yang dihasilkan biasanya pendek (1,3 sampai 20 centimeter). Sampai saat ini kebutuhan serat untuk tekstil sebagian besar diperoleh dari
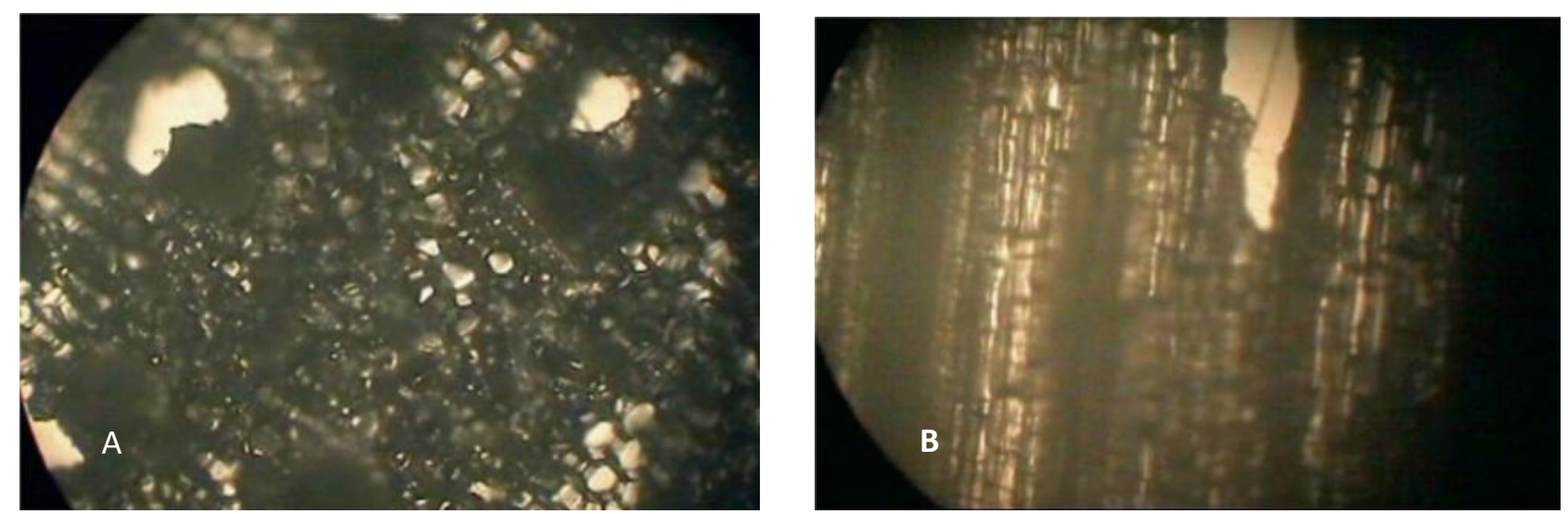

Gambar 1 Penampang rumput teki secara (A) melintang dan (B) membujur
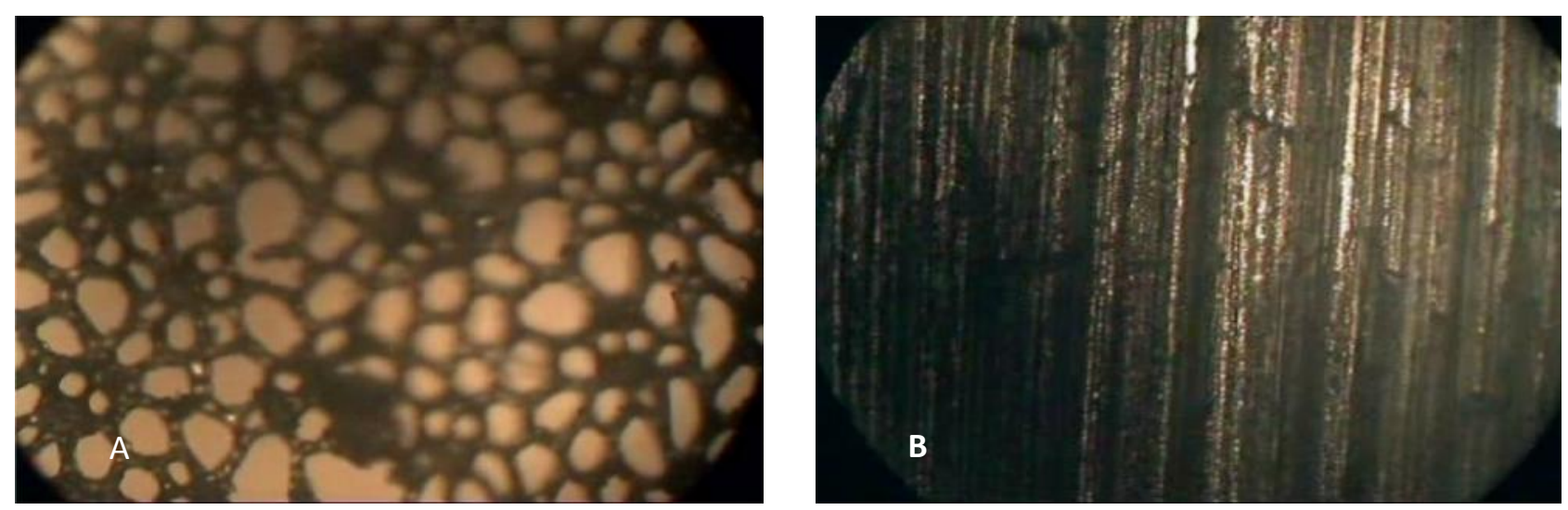

Gambar 2 Penampang rumput sianik secara (A) melintang dan (B) membujur 
kapas. Kapas yang seratnya paling pendek dapat dipintal berkat sifatnya cenderung membentuk spiral. Sementara itu serat yang dihasilkan oleh rumput sianik yang telah dikeringkan berkisar antara $5-10 \mathrm{~cm}$, ini berarti serat sianik dapat dipintal menjadi benang ataupun tali.

Kadar air rumput teki (Fimbristylis sp), sianik (Carex sp) dan linggi (Panicum sp). Kadar air merupakan bagian yang perlu diperhatikan pada serat yang akan dijadikan bahan alat penangkapan ikan. Kandungan kadar air pada serat dapat mempengaruhi sifat kemampuan menyerap air dan pada akhirnya akan mempengaruhi kecepatan tenggelam bahan tersebut. Semakin tinggi daya serap suatu serat maka cenderung semakin cepat pulalah kecepatan tenggelam bahan tersebut.

Berdasarkan hasil pengamatan, kadar air yang dimiliki oleh rumput teki rata-rata 69,0\% dari berat serat. Dilihat dari nilai kadar air yang dimiliki rumput teki maka rumput ini cenderung memiliki kecepatan tenggelam yang lambat, jika dibandingkan dengan kedua rumput lainnya. Semakin banyak kadar air yang dimiliki maka semakin banyak rumput ini menyerap air, sehingga waktu untuk bisa tenggelam akan semakin lama. Lamanya waktu yang dibutuhkan oleh jenis rumput ini untuk tenggelam merupakan satu alasan mengapa rumput ini tidak cocok digunakan untuk menjadi bahan tali. Adapun selengkapnya hasil pengukuran kadar air yang diamati dapat dilihat pada Tabel 1.

Berdasarkan tabel tersebut, selama 10 hari pengeringan cahaya matahari udara terbuka kemampuan daya serap air rumput teki ini rata-rata dapat mencapai sekitar 1,0 gram air. Kemampuan daya serap ini dibandingkan pula dengan kemampuan daya serap air rumput linggi dan sianik. Hasil pengukuran kadar air pada rumput sianik rata-rata berkisar 3,6 gram. Kadar air tersebut lebih tinggi jika dibandingkan dengan kadar air yang dimiliki oleh rumput teki dan linggi.
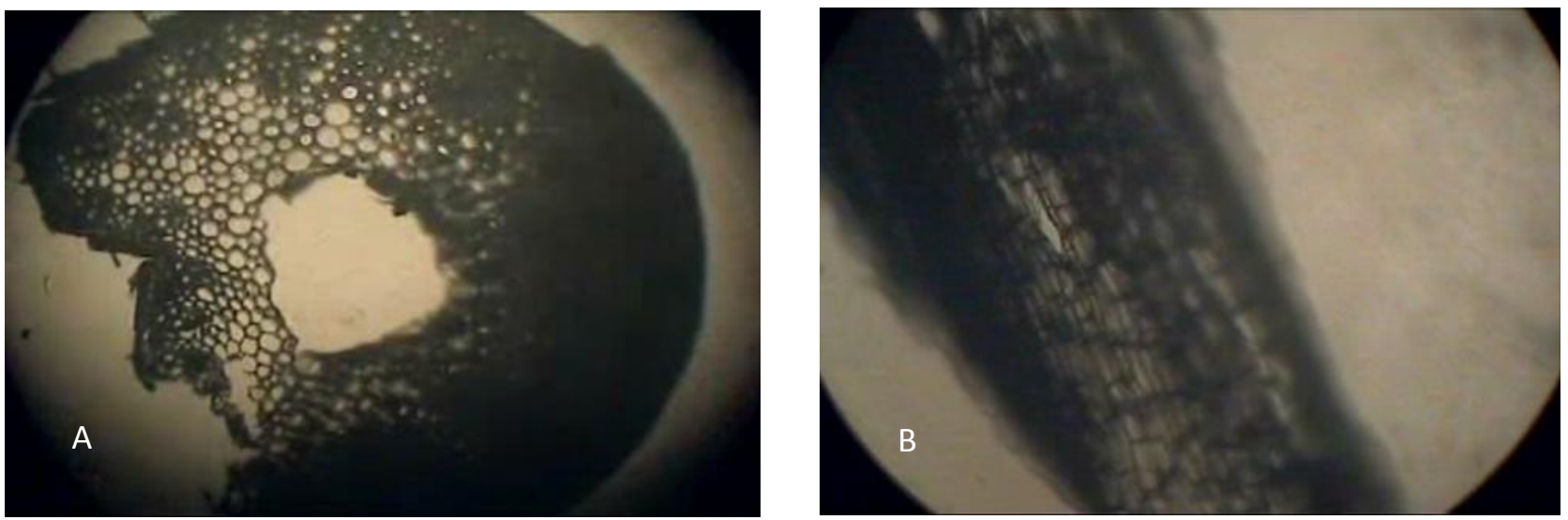

Gambar 3 Penampang rumput linggi secara (A) melintang dan (B) membujur
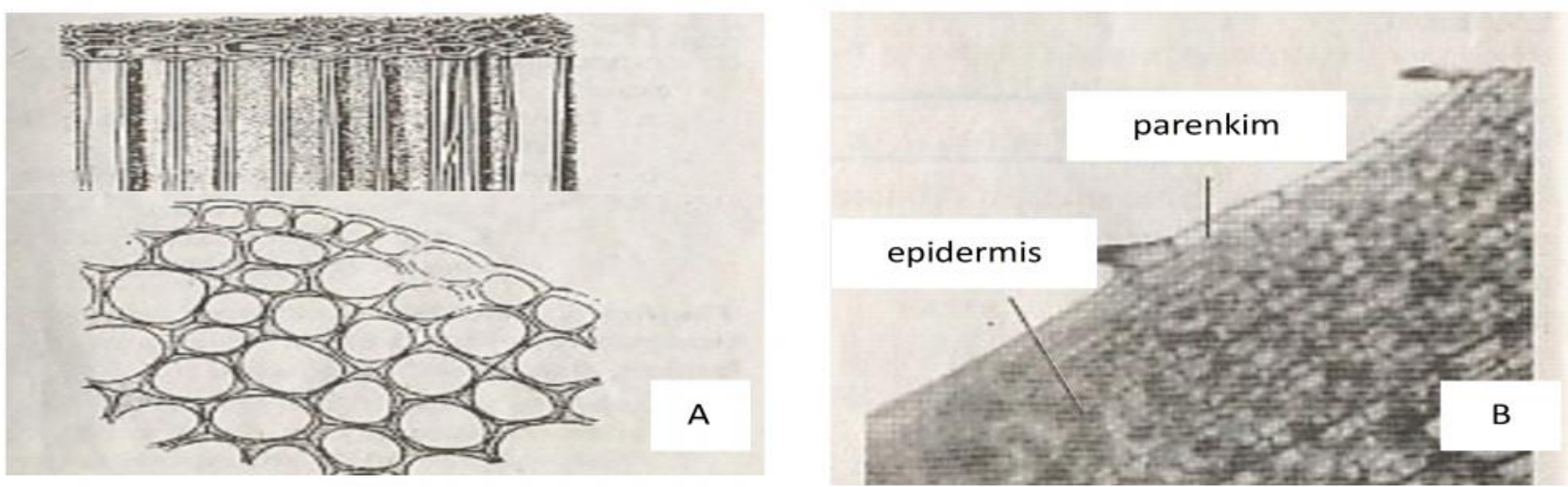

Gambar 4 Struktur parenkim dan epidermis linggi

Tabel 1 Kandungan kadar air, Kekuatan Putus dan Kemuluran rumput (Fimbristylis sp), Sianik (Carex sp) dan Linggi (Penicum sp)

\begin{tabular}{lcrr}
\hline & $\begin{array}{c}\text { Teki } \\
\text { (Fimbristylis } \text { sp) }\end{array}$ & \multicolumn{1}{c}{$\begin{array}{c}\text { Lianik } \\
\text { (Carex } \text { sp) }\end{array}$} \\
\hline Kadar Air (grm) & 1,0 & 3,6 & 0,2 \\
Kadar Air (\%) & 69,0 & 67,5 & 54,8 \\
Kekuatan Putus Basah (Kgf) & 3,2 & 9,1 & 4,2 \\
Kekuatan Putus Kering (Kgf) & 4,3 & 9,8 & 12,2 \\
Kemuluran Basah (mm/Kgf) & 9,1 & 12,9 & 24,5 \\
Kemuluran Kering (mm/Kgf) & 11,1 & & 18,8 \\
\hline
\end{tabular}


Berdasarkan pengukuran kemampuan daya serap air rumput linggi ialah 0,2 gram (Tabel 1). Kemampuan daya serap air rumput linggi ini juga lebih rendah jika dibandingkan dengan rumput sianik. Berdasarkan daya serap air yang dimiliki oleh serat rumput sianik, ia relatif lebih kuat dari pada serat rumput linggi dan teki. Kemampuan daya serap air tersebut akan berpengaruh terhadap kecepatan tenggelam dari bahan itu sendiri. Sementara itu, kecepatan tengelam yang cepat dibutuhkan oleh beberapa jenis alat tangkap untuk dapat meningkatkan efisiensi waktu operasi alat tangkap tersebut.

Kekuatan Putus Serat Rumput Teki (Fimbristylis sp), Sianik (Carex sp) dan Linggi (Panicum sp). Sebagai salah satu syarat yang harus dimiliki oleh serat untuk dijadikan tali ataupun benang pada alat penangkapan ikan adalah memiliki kekuatan putus yang baik. Serat yang memiliki kekuatan putus yang baik akan menghasilkan tali atau benang yang kuat. Persyaratan ini mutlak harus dimiliki oleh setiap bahan alat penangkapan ikan dikarenakan beban yang diberikan pada tali atau benang pada saat dioperasikan sangatlah berat. Untuk dapat mengetahui kekuatan putus serat dari rumput teki ini, maka dilakukanlah pengujian dengan menggunakan strength tester. Hasil pengujian rumput teki dapat dilihat pada Tabel 1.

Jika dibandingkan kekuatan putus serat rumput teki dengan rumput linggi dan sianik, maka rumput teki memiliki peluang yang kecil untuk dapat diolah atau dianyam menjadi tali sebagai bahan alat penangkapan ikan. Hal ini disimpulkan berdasarkan nilai kekuatan putus rumput teki ini relatif lebih kecil dibandingkan dengan kedua rumput lainnya. Berdasarkan perhitungan yang dilakukan dengan menggunakan uji-t untuk mengetahui apakah ada perbedaan kekuatan putus antara rumput teki saat basah dengan rumput teki saat kering. Dari hasil perhitungan didapat bahwa thitung $(3,8)$ lebih besar dari t-tabel $(2,8)$ pada tingkat kepercayaan $95 \%$ berarti ada pengaruh kekuatan putus antara rumput teki saat kering dengan rumput teki saat basah. Ternyata pada Tabel 1 dapat dilihat adanya perbedaan kekuatan putus antara rumput teki saat basah dengan rumput teki saat kering. Kekuatan putus rumput teki saat kering rata-rata 4,3 kgf lebih kuat dari rumput teki saat basah, yaitu rata-rata 3,2 kgf. Kadar air yang terdapat pada serat rumput teki mengurangi kekuatan struktur serat tersebut. Hal ini mengindikasikan rumput teki tidak cocok untuk dijadikan bahan alat penangkapan ikan.

Berdasarkan perhitungan yang dilakukan dengan menggunakan uji-t untuk mengetahui apakah ada perbedaan kekuatan putus antara rumput sianik saat basah dengan rumput sianik saat kering. Dari hasil perhitungan didapat bahwa t-hitung $(1,7)$ lebih kecil dari t-tabel $(2,8)$ pada tingkat kepercayaan $95 \%$ berarti tidak ada pengaruh kekuatan putus antara rumput sianik saat kering dengan rumput sianik saat basah.

Berdasarkan kekuatan putus yang dimiliki oleh rumput sianik saat basah $(9,1 \mathrm{kgf})$ dan saat kering $(9,8 \mathrm{kgf})$, maka rumput ini berpotensi untuk diolah menjadi benang yang akan digunakan alat penangkapan ikan. Karena kekuatan putus rumput sianik ini lebih besar dari standar kekuatan putus benang rami dan katun. Menurut Lenkosmanerri (1998), bahwa kekuatan putus benang rami dan benang katun adalah 2,9 kgf dan 2,5 kgf, sedangkan kemulurannya (benang rami dan katun) adalah 11,9 $\mathrm{mm}$ dan 17,2 $\mathrm{mm}$. Sedangkan Mukhlis, (1999) melaporkan bahwa nilai kekuatan putus benang rami dan katun adalah 3,0 kgf dan 4,2 kgf. Ditambahkan lagi oleh Wahyuni (2002) yang menyatakan bahwa benang katun yang memiliki diameter $0,9 \mathrm{~mm}$ nilai kekuatan putus dan kemulurannya 0,62 kgf dan 13,2 mm. Berdasarkan penelitian terdahulu nilai kekuatan benang serat rami relatif lebih rendah dari pada serat rumput teki. Hal ini merupakan suatu alasan yang kuat bahwa rumput sianik adalah rumput yang potensial dapat diolah sebagai bahan baku untuk tali atau benang pada alat penangkapan ikan.

Dari hasil perhitungan didapat bahwa t-hitung $(4,4)$ lebih besar dari t-tabel $(2,8)$ pada tingkat kepercayaan $95 \%$. Artinya ada pengaruh kekuatan putus antara rumput linggi saat kering dengan rumput linggi saat basah. Karena struktur serat rumput linggi dalam keadaan basah lebih lemah jika dibandingkan dalam keadaan kering. Sedangkan struktur serat rumput sianik dan teki tidak ada perbedaannya, baik dalam keadaan basah maupun kering. Tingginya kekuatan putus serat alami pada kondisi kering dikarenakan kadar air dapat mempengaruhi struktur serat. Struktur serat alami pada kondisi kering lebih stabil jika dibandingkan pada kondisi lembab. Hal ini, merupakan salah satu kelemahan serat alami dari serat sintetis. Serat alami sebagian besar terdiri dari selulosa, sehingga kadar air dapat juga menimbulkan pelapukan yang cepat. Kondisi lembab dan terendam air membuat bahan alat penangkapan yang berasal dari serat alami akan mudah diserang oleh mikro organisme pemakan selulosa dari jenis bakteri. Sehingga, bahan tersebut akan kehilangan kekuatan (Klust 1987).

Kekuatan putus adalah kekuatan maksimal yang diperlukan untuk membuat putusnya bahan dalam uji pada 
tegangan tertentu. Biasanya ditetapkan dalam satuan kilogram gaya (kgf) (Klust 1987). Berdasarkan kekuatan putus yang dimiliki oleh rumput linggi saat basah $(4,1 \mathrm{kgf})$ dan saat kering $(5,5 \mathrm{kgf})$, maka rumput linggi ini bisa diolah menjadi benang untuk digunakan alat tangkap ikan, karena kekuatan putus rumput linggi ini lebih besar dari standar kekuatan putus benang rami dan katun.

Jika dibandingkan kekuatan putus serat rumput linggi dan teki, kekuatan rumput linggi lebih baik daripada rumput teki yaitu dengan selisih $0,9 \mathrm{kgf}$ pada saat basah dan $0,9 \mathrm{kgf}$ pada saat kering. Tetapi, jika dibandingkan dengan kekuatan putus rumput sianik, rumput linggi jauh lebih kecil, yaitu dengan selisih kekuatan putus $4,8 \mathrm{kgf}$ pada saat basah dan 4,5 kgf pada saat kering.

Kemuluran Serat Rumput Teki (Fimbristylis sp), Sianik (Carex sp) dan Linggi (Panicum sp). Kemuluran didefinisikan sebagai suatu pertambahan panjang dari suatu contoh uji yang menggunakan ketegangan dan dinyatakan dalam satuan panjang, misalnya centimeter atau milimeter (Klust 1987). Tingkat kemuluran suatu serat sangat erat kaitannya dengan kekuatan putus serat itu sendiri. Kemuluran berkaitan pula dengan tingkat elastisitas suatu serat. Semakin tinggi tingkat kemuluran ataupun elastisitas suatu serat maka kekuatan putusnya cenderung akan tinggi pula. Tetapi, berbeda halnya dengan rumput linggi, kemulurannya lebih tinggi dari pada rumput teki dan sianik. Sedangkan kekuatan putusnya lebih lemah dibandingkan kedua rumput tersebut. Hasil uji kemuluran serat rumput teki berkisar 9,1 kgf pada saat basah dan 11,1 kgf pada saat kering. Tentang hasil pengukuran tingkat kemuluran rumput teki selengkapnya dapat dilihat pada Tabel 1.

Berdasarkan Tabel 1, nilai kemuluran serat rumput teki relatif lebih kecil jika dibandingkan dengan rumput linggi (Penicum sp) dan rumput sianik (Carex sp). Selisih rata-rata tingkat kemuluran serat rumput teki dan linggi dalam keadaan basah adalah 3,1 mm/kgf. Sedangkan antara rumput teki dan sianik adalah 15,4 mm/kgf. Begitu pula tingkat kemuluran rumput teki dalam keadaan kering, jika dibandingkan dengan rumput linggi dan sianik. Rata-rata tingkat kemuluran rumput teki lebih kecil dibandingkan dengan rumput linggi sekitar $1,8 \mathrm{~mm} / \mathrm{kgf}$. Sedangkan rata-rata perbandingan antara rumput teki dan sianik dalam keadaan kering lebih kecil sekitar 7,6 mm/kgf.

Menurut Klust (1987), supaya alat penangkapan mencapai elastisitas yang tinggi, maka perlu diperhatikan segala aspek yang mempengaruhi kestabilan, seperti kekuatan putus dan kemuluran. Tingkat kemuluran merupakan salah satu prasyarat pula yang harus dimiliki oleh bahan alat penangkapan ikan. Di beberapa kasus dalam proses tertangkapnya ikan oleh alat tangkap dipengaruhi pula oleh kemuluran bahan alat tangkap itu sendiri. Contohnya pada alat tangkap jaring tinggi rendahnya keberhasilan tertangkapnya ikan oleh alat tangkap jaring insang sangat dipengaruhi oleh bahan mata jaring yang digunakan. Benang yang elastis akan lebih mudah menjerat ikan pada saat menerobos jaring dari pada benang yang lebih kaku.

Berkaitan dengan hal tersebut di atas menurut Martasuganda (1999), selektivitas jaring insang dipengaruhi oleh kelenturan bahan dari jaring tersebut. Kelenturan jaring akan mempengaruhi ikan merasakan benang sebagai perangkap/serat oleh indra yang terdapat pada tutup insang yang dinamakan sebagai titik beta. Titik inilah yang dapat merasakan keberadaan jaring yang akan dilalui oleh ikan tersebut. Jika benang/kenur relatif lebih lentur maka keberadaan benang akan relatif lebih sulit diketahui oleh ikan melalui bagian indra tersebut.

Hasil perhitungan yang dilakukan dengan menggunakan uji-t untuk mengetahui apakah ada perbedaan kemuluran antara rumput sianik saat basah dengan rumput sianik saat kering diperoleh bahwa t-hitung $(4,2)$ lebih besar dari t-tabel $(2,9)$ pada tingkat kepercayaan $95 \%$ berarti ada pengaruh kemuluran antara rumput sianik saat kering dengan rumput sianik saat basah. Terdapat perbedaan kemuluran antara rumput sianik saat basah dengan rumput sianik saat kering. Ternyata kemuluran rumput sianik saat kering yang rata-ratanya $18,7 \mathrm{~mm}$ memiliki kemuluran yang lebih kecil dari pada rumput sianik saat basah yang rataratanya $24,5 \mathrm{~mm}$. Sedangkan berdasarkan nilai kemuluran yang dimiliki oleh rumput sianik saat basah $(24,5 \mathrm{~mm})$ dan saat kering (18,8 mm), maka rumput sianik ini bisa diolah menjadi benang untuk digunakan sebagai alat tangkap ikan, karena kemuluran rumput sianik ini lebih besar dari standar kemuluran benang rami dan katun. Berdasarkan nilai kekuatan putus dan kemuluran rumput sianik yang didapat dan selanjutnya dibandingkan dengan standar nilai kekuatan putus dan kemuluran, maka dapat diketahui bahwa rumput sianik ini cocok dijadikan sebagai bahan dasar untuk pembuatan benang. Dalam keadaan kering dan basah kemungkinan pelapukan kecil, akibat perbedaan yang kecil.

Hamidy et al. (1982), menyatakan bahwa banyak benang berserabut (serat) mempuyai kemuluran lebih besar dari benang yang berserabut sedikit. Sementara Murdiyanto (1975), menambahkan bahwa dalam penentuan bahan alat 
tangkap yang akan dipergunakan untuk pembuatan suatu jaring baik berupa twine, roop, float, sinker dan sebagainya maka akan berhadapan dengan beberapa pertimbangan antara lain: kekuatan, ketahanan, warna, harga dan sebagainya. Bahan ini dipengaruhi oleh serat pembentuknya. Serat yang berasal dari tumbuhan berasal dari parenkim dan epidermis. Oleh karena itu, komposisi dan struktur parenkim dan epidermis sangat menentukan sifat suatu serat tersebut, termasuk sifat kekuatan putus, kemuluran, dan daya serap air serat tersebut.

Perhitungan yang dilakukan dengan menggunakan ujit untuk mengetahui apakah ada perbedaan kemuluran antara rumput linggi saat basah dengan saat kering. Dari hasil ujit didapat bahwa t-hitung $(0,6)$ lebih kecil dari t-tabel $(2,8)$ pada tingkat kepercayaan $95 \%$; berarti tidak ada pengaruh kemuluran antara rumput linggi saat kering dengan saat basah. Dari Tabel 1 di atas dapat dilihat tidak adanya perbedaan kemuluran antara rumput linggi saat basah dengan saat kering. Ternyata kemuluran rumput linggi saat kering yang rata-ratanya $12,9 \mathrm{~mm}$ memiliki kemuluran yang lebih besar dari pada saat basah yang rata-ratanya 12,2 mm.

Wahyuni (2002), menyatakan bahwa benang katun yang memiliki diameter $0,9 \mathrm{~mm}$ yang belum diawetkan memiliki kemuluran 0,6 kgf dan 13,2 mm. Sedangkan nilai kemulurannya benang rami adalah berkisar 15,7 mm dan 13,9 $\mathrm{mm}$, dengan diameter benang pada saat diuji yaitu $0,7 \mathrm{~mm}$ (Mukhlis 1999). Jika dibandingkan kemuluran yang dimiliki oleh serat rumput teki dengan rami dan katun terlihat bahwa tingkat kemuluran rumput tersebut relatif lebih besar. Berarti dalam penangkapan, sebagai tali atau bahan jaring yang dioperasikan di perairan yang arusnya deras atau beban hasil tangkapan yang berat, kemuluran yang tinggi/panjang lebih tahan terhadap tegangan yang berasal dari ikan maupun gaya dari perairan penangkapan.

\section{SIMPULAN}

Bedasarkan pengamatan histologi, kadar air, uji kekuatan putus dan kemuluran rumput sianik merupakan bahan dasar yang cocok dijadikan bahan alat penangkapan ikan jika dibandingkan dengan rumput teki dan linggi. Hal ini dikarenakan rumput sianik memiliki struktur serat (jaringan parenkim dan kolenkim) dan lapisan dermis (lapisan urat serat tumbuhan, lapisan jaringan penghubung dan lapisan perasa) yang lebih lengkap jika dibandingkan dengan struktur serat pada rumput teki dan linggi. Selain itu, kekuatan putus dan kemuluran rata-rata rumput sianik lebih tinggi jika dibandingkan dengan rumput teki dan linggi.
Berdasarkan kesimpulan di atas, penulis menyarankan agar dilakukan penelitian lanjutan mengenai rumput sianik (Carex sp) yang diolah menjadi benang atau tali dan jaring, kemudian dilakukan uji kekuatan putus dan kemulurannya.

\section{UCAPANTERIMAKASIH}

Terima kasih kami aturkan sebesar-besarnya kepada semua pihak yang telah membantu dalam penelitian ini. Terutama kepada seluruh staf pengajar Jurusan Pemanfaatan Sumberdaya Perairan, Fakultas Perikanan dan Ilmu Kelautan, Universitas Riau. Terima kasih tidak lupa kami ucapkan kepada staf Marine Stasiun Purnama Dumai.

\section{DAFTAR PUSTAKA}

Ataladjar, B.T. 1991. Ensiklopedia. Jakarta: Adi Cipta Pustaka. Asrianto. 1978. Penelitian tentang besar shortening dan bahan webbing trammel net di perairan Pemalang Jawah Tengah. Skripsi Fakultas Perikanan Universitas Dipenogoro. Semarang: UNDIP.

Cole, R.C. \& Rogers, J.F. 1985. The construction and repair of fishing gear. Di dalam: Hand book for junior fishing officers. Part 2. Tropical Development and Research Institute. London.

Dinas Perikanan Tingkat I Riau. 1996. Tinjauan perkembangan teknologi penangkapan di pandang dari sudut kebijaksanaan pemerintah makalah. Pekanbaru.

Hamidy, Y. Ahmad, M. \& Alawi, H. 1982. Kekuatan benang bahan alat penangkapan ikan yang direndam dalam air tawar dan air laut. Laporan Penelitian. Pekanbaru: Lembaga Penelitian Universitas Riau.

Hartanto, N.S. \& Watanabe, S. 1979. Pusat Teknologi Tekstil. Jakarta: PT. Pradaya Paramita.

Klust, G. 1987. Bahan jaring untuk penangkapan ikan. Diterjemahkan oleh Tim BPPI Semarang. Edisi ke II. Bagian Proyek Pengembangan Teknik Penangkapan Ikan. Semarang: Balai Pengembangan Penangkapan Ikan.

Martasuganda, S., Ogura, Y., Matsuoka, Y. \& Kawamura, G. 1999. Shoku shigeki ni tai suru teta pointo to amime ni sogu shita sakana no zenshin kodo he no eikyo. Nisuishi 65: 991997.

Mukhlis. 1999. Kekuatan putus (breaking strength) dan kemuluran (elongation) benang katun dan rami yang diawetkan dalam darah sapi (bos taurus) dengan konsentrasi yang berbeda. Skripsi Fakultas Perikanan dan Ilmu Kelautan. Pekanbaru: UNRI.

Murdiyanto, B. 1975. Suatu pengenalan tentang fishing gear material. Bagian Penangkapan Ikan. Bogor: Fakultas Perikanan Institut Pertanian Bogor.

Sandoz, L.T.D. 1952. Application of acetilated cellulose for fishing gear. Di dalam: Kristjonsson. H (ed). Modern Fishing Gear of The World. London: Fishing News (books) Ltd.

Wahyuni, S. 2002. Kekuatan putus (breaking strength) dan kemuluran (Elongation) Benang Katun yang diawetkan dalam campuran Bahan Pengawet Alami Nyirih (Xilocapus moluccensis M. Roem), Jarak (Ricinus communis L), Ubar (Adinandra acuminata). Skripsi Fakultas Perikanan dan Ilmu Kelautan. Pekanbaru: UNRI.

Xiao, J., Zeng, J., Wang, C., Wang, C., Liang, C., Chen, Y., Zhang, X. \& Lou, B. 2000. Status of research and development for the natural high performance fiber reinforced composite and its product. Fiber Reinforcement plastic/ composite. Beijing: Tsinghua Tongfang Knowledge Network Technology Co., Ltd. 